\title{
Detection of bovine rotavirus in diarrheic calves by using rapid test in some Mid-Euphrates provinces
}

\author{
Hahmed Abass Hassan Q Qassim Haleem Kshash Kalefa Ali Mansur \\ Coll. of Vet. Med./ Univ. of Al-Qadisiya \\ email: q_ksahsh@yahoo.com
}

(Received 30 September 2013, Accepted 3 November 2013)

\begin{abstract}
The study was aimed to determine the Rota viral infection rates in diarrheic calves and effectiveness of some epidemiological factors on that rate in some provinces in MidEuphrates region in Iraq (Babylon, Al-Najaf, Karbala, Al-Qadisyia provinces). A total of 530 calves aged between 1-60 day were examined and fifty fecal (50) samples were collected from diarrheic calves only within six months period from November-2012 to April -2013. The fecal samples were examined for the presence of rotavirus by rapid rotavirus test (screening test), as well as the clinical examination for these diarrheic calves were done. The rapid test demonstrated that the rotavirus infection rate was $18 / 50$ (36\%). A $45.4 \%$ of rotavirus infection was found in calves less than 30 days of age which was significantly higher than $28.5 \%$ calves (30-60) days old. Male and female (37.5\%, 40\% respectively) were seen infected without any significant differences. The main clinical signs observed on rotavirus diarrheic calves were include, watery voluminous diarrhea with profound weakness and mild depression, so as temperature, respiration, heart rates could be decreased and appetite was changeable towards loss or anorectic. In Babylon, the highest rotavirus infection rate was recorded 60\%, and less rates in Karbala 20\% and 40\%, 33\% in AL-Najaf and AL-Qadisyia provinces respectively. The rotavirus infection rate in diarrheic calves was affected by months significantly, which it was higher at January $75 \%$, so as in November $50 \%$, December $40 \%$ and February $33.3 \%$, but not recorded in March and April.
\end{abstract}

Key words: Rota virus, diarrhea, calf, rapid test.

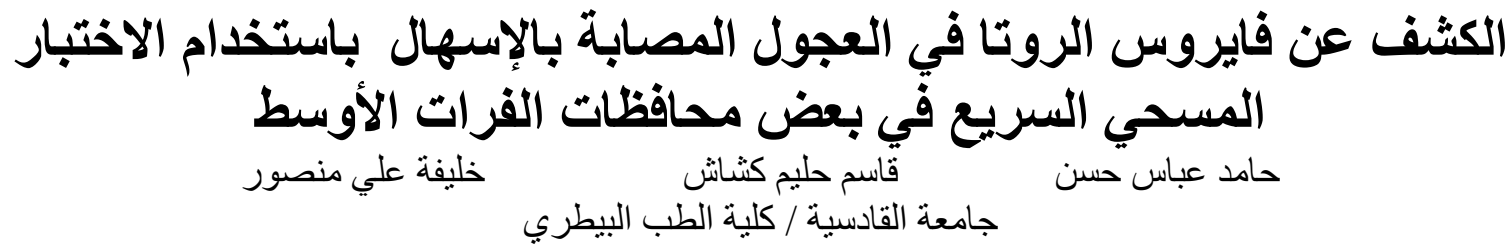

الخلاصة

تضمنت هذه الدراسة تحديد معدلات الإصـابة بفايروس الروتا في العجول المصابة بالإسهال وتأثيثير بعض العابل العوامل

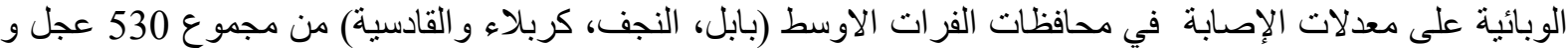

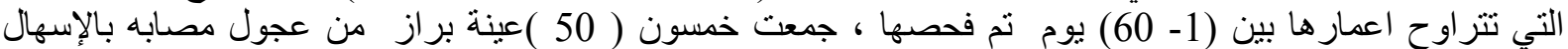

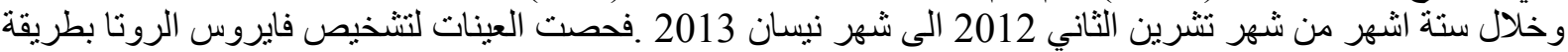

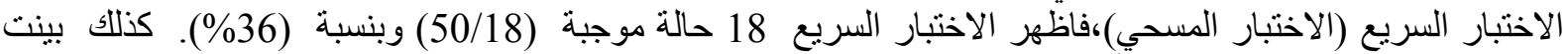

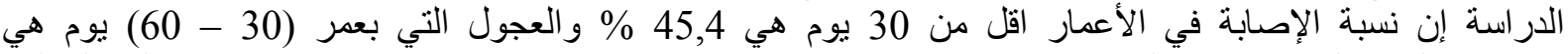

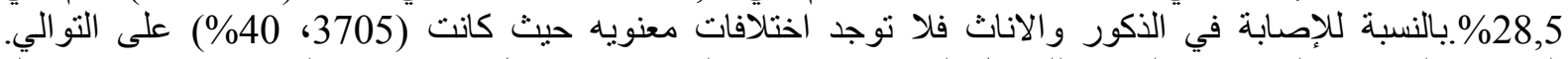

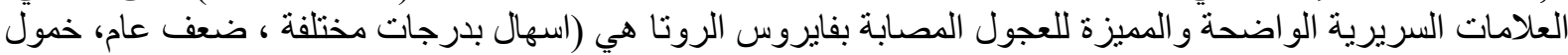

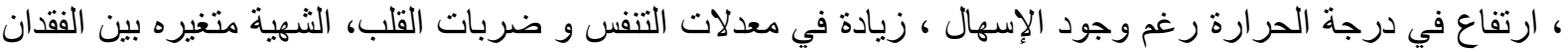

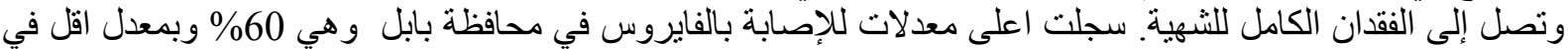

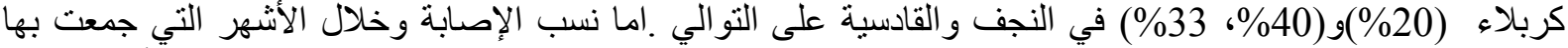

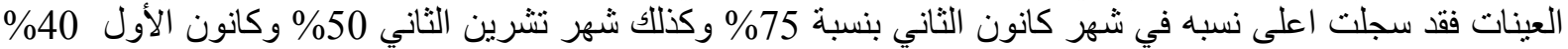

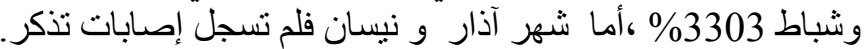

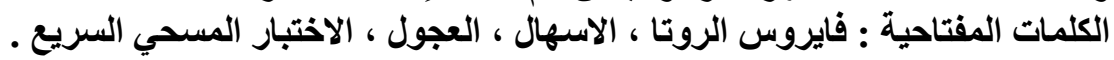




\section{Introduction}

Neonatal diarrhea is a worldwide problem and its seen as one of the biggest challenges for both the beef and dairy industry (1). Many infectious or non infectious agents play role in newborn calves with diarrhea ,there are many infectious agents e.g., rotavirus, coronavirus, astrovirus, calicvirus, as well as E-coli, salmonella spp, shigella responsible for newborn calves with diarrhea in tie -sall barns (2). Mainly rotavirus lead to loss in many species of newborn ,human including too (3). Many studies have been showed $50 \%$ of newborn deaths due to diarrhea in calves rotavirus infections constitute the basic causes of economic loss owing to grow delay, birth of weak calves and high mortality levels in herds (2). Rotaviruses are now recognized as the most important cause of severe viral gastroenteritis in humans (4), and are also major infectious cause of diarrhea in calves (5). Rotavirus infection in cattle is worldwide distribution which obtained by (6) in Brazil as $19.4 \%$, in Turkey $10.5 \%$ (7), in Sweden between 1993 and 2006 as $24-47 \%$ ( 8),also in UK the $42 \%$ (9), in Costa Rica 7\% (10), in calves in Ohio 16\% (11) and 47\% in south-west France (12), $27 \%$ in India by (13), $16.8 \%$ in Southern Italy (14). Also in Iraq was reported in ALMosul 15.5\% and in AL-Basrah 25\% (15), (16). Conventional techniques like rapid bovine rotavirus test, electron microscopy (EM), isolation in MA-104 cell line, electropherotyping, and various serological tests as well as PCR technique are used for diagnosis of rotavirus (17). To investigate $\mathrm{e}$ about rotavirus as one of many important causative agent of neonate diarrhea in calves, the present study was designed in some MidEuphrates regions in Iraq.

\section{Materials and methods}

\section{Materials:}

\section{One Step Rotavirus Rapid Test device:}

One Step Rotavirus Rapid Test device kit was used in this study was manufactured by Acon company /Germany.

\section{Principles:}

The Antigen Rapid test (Rota Ag Test) Kit is a chromatographic immunoassay for the qualitative detection of Rota virus, group A antigen in porcine, bovine and canine feces with high degree of accuracy. The specially selected Rota virus antibodies are used in test band as both capture and detector materials.

\section{Procedure of the test :}

Collect the samples from calves feces using the swab, then insert the swab into the specimen tube containing $1 \mathrm{ml}$ of assay diluents and mix the swab samples with assay diluents to extract well, after that remove the test device from the foil pouch, and place it on a flat and dry surface, then using the disposable dropper provided, take the samples from extracted and mixed specimens in the tube and add four (4) drops into the sample hole using the disposable dropper, drop by drop, then as the test begins to work, you will see purple color move across the result window in the center of the test device. If the migration has not appeared after 1 minute, add one more drop of the mixed assay diluents to the sample well. For best result, test 5 diarrhea feces in the farm. Interpret test results at $5 \sim 10$ minutes. Do not decide after 20 minutes.

\section{Interpretation of the test:}

1) A color band will appear in the left section of the result window. This means that the test is working properly. This band is the control band. The right section of the result window indicates the test results. If another color band appears in the right section of the result window, it means that the specimens have the Rota virus antigens (Fig.1 positive, and Fig. 2 negative).

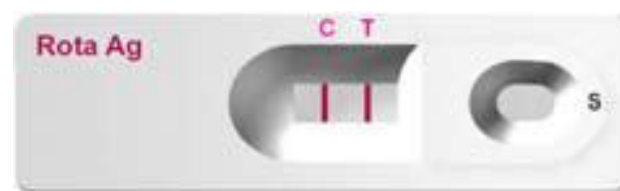

Figure(1):Two color bands show positive result of rotavirus to rapid test.

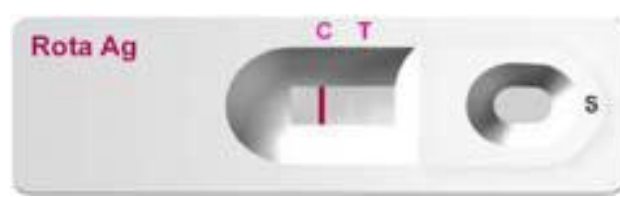

\section{Figure(2): One color band show negative result of rotavirus to rapid test.}

2) If the purple color band is not visible within the result window after performing the 
test, the result is considered invalid. The directions may not have been followed correctly or the test kit may have deteriorated. It is recommended that the specimen be re-tested.

\section{Methods}

\section{Clinical study}

Five hundred and thirty newly calves were examined and 50 fecal samples were collected from acutely diarrheic calves with age grouped between 1- 60 day by aseptic methods (per rectally using gloved finger) taking care of all precautions so as to avoid contamination of samples, which kept in sterilized plastic containers, transported under cold (ice) conditions and stored at -20 c (deep freezing) till further processing. Samples were collected over a period of six months duration from November 2012 to April 2013 from different farms and animal sale lands in many provinces (Babylon 17, AL-Najaf 10, Karbalaa 12, and AL- Qadisyia 11). The data was obtained by questionnaire paper which designed and included animal owners name, date, area, breed, sex, age, of calves, also temperature , respiratory and heart rates and other apparent clinical signs, consistency and color of feces and any note may be observed.

\section{Statistical analysis}

The data was analyzed by using statistical package for the social sciences(SPSS)version 16 software program (2007).

\section{Results}

Out of 530 calves were examined there were only 50 calves suffering from various types of diarrhea, therefore $19.43 \%$ of examined calves in present study were diarrheic as well as there was no significant effect of calves sex on diarrhea percentage as $10.04 \%$ in male and $9.03 \%$ in female, table (1). The results of rapid test showed that 18 out of 50 fecal samples of diarrheic calves were positive into rotavirus at percentage (36\%), table (2). The main clinical signs observed on rotavirus diarrheic calves were include, watery voluminous yellowish or bloody diarrhea with profound weakness and mild depression, so as temperature, respiration, heart rates could be decreased and appetite was changeable towards loss or anorectic. The result showed there was nonsignificant effect of sex rates of calves on infection rates by BRV which $37.5 \%$ in male and $40 \%$ in female, table (3). The results of infection rate according to age groups (1-29 days,30 -60 days) were $(45.4 \%, 28.5 \%$, respectively, the result showed that the highest rate of infection $45.4 \%$ were in age group (1 -29 days), while age group (30 - 60 days) had taken the lowest infection rate $28.5 \%$. Statically, there was significant effect $(\mathrm{p}<0.05)$ age groups 1-29 days on BRV infection rate, table (4). The effect of infection rates according to the months of the year were $(50 \%, 40 \%, 75 \%, 33.3 \%, 0 \%$, and $0 \%$ ) at (November, December, February, January, March, and April) respectively. The highest significant percentage rates of infection shared, January $75 \%$, while in February had record the lowest infection rate. But infection not recommended in March and April, table (5). Rotavirus infection rates in the different provinces (Babylon, AL-Najaf, Karbala, and AL-Qadisyia ) were $60 \%, 40 \%, 20 \%$, and $33.3 \%$, respectively. The highest rates were in Babylon $60 \%$ while the lowest one was in Karbala $20 \%$. Statically, There was significant differences in BRV infection at $(p<0.05)$ between Babylon with AL-Najaf and Karbala. The significant differences at $(\mathrm{p}<0.05)$ between Karbala with AL-Najaf and AL-Qadisyia , and significant differences on $(\mathrm{p}<0.05)$ between Karbala and ALQadisyia. No significant differences on $(\mathrm{p}<$ $0.05)$ between Babylon and AL-Qadisyia, table (6).

\section{Table (1): Percentage of diarrhea among examined young calves.}

\begin{tabular}{|c|c|c|c|}
\hline $\begin{array}{c}\text { calves } \\
\text { sex }\end{array}$ & $\begin{array}{c}\text { Number of } \\
\text { Examined } \\
\text { calves }\end{array}$ & $\begin{array}{c}\text { Number of } \\
\text { Diarrheic } \\
\text { calves }\end{array}$ & $\begin{array}{c}\text { Diarrhea } \\
\text { rate (\%) }\end{array}$ \\
\hline Male & 209 & 21 & $10.04 \mathrm{a}$ \\
\hline Female & 321 & 29 & $9.03 \mathrm{a}$ \\
\hline Total & 530 & 50 & 19.43 \\
\hline Similar letters refers to the non-significant
\end{tabular}

differences $(p>0.05)$.

\section{Table(2): Results of rapid rotavirus test.}

\begin{tabular}{|c|c|c|}
\hline $\begin{array}{c}\text { No. of examined } \\
\text { samples }\end{array}$ & $\begin{array}{c}\text { No. of } \\
\text { positive } \\
\text { samples }\end{array}$ & $\begin{array}{c}\text { Infection } \\
\text { rate \% }\end{array}$ \\
\hline 50 & 18 & 36 \\
\hline
\end{tabular}


Table(3):Bovine rotavirus in calves, the rate of infection in relation to the sex.

\begin{tabular}{|c|c|c|c|}
\hline Sex & No. of samples & positive & $\%$ \\
\hline Male & 8 & 3 & $37.5 \mathrm{a}$ \\
\hline Female & 10 & 4 & $40 \mathrm{a}$ \\
\hline Total & 18 & 7 & 38.8 \\
\hline
\end{tabular}

Similar letters refers to the non-significant differences between sex at $(p>0.05)$.

Table(5): The effect of the months on infection rate in calves by rotavirus.

\begin{tabular}{|l|c|c|c|}
\hline Months & $\begin{array}{c}\text { No. of } \\
\text { samples }\end{array}$ & positive & $\%$ \\
\hline November & 2 & 1 & $50 \mathrm{a}$ \\
\hline December & 5 & 2 & $40 \mathrm{a}$ \\
\hline January & 4 & 3 & $75 \mathrm{~b}$ \\
\hline February & 3 & 1 & $33.3 \mathrm{ac}$ \\
\hline March & 3 & 0 & 0 \\
\hline April & 1 & 0 & 0 \\
\hline Total & 18 & 7 & 38.8 \\
\hline
\end{tabular}

Similar letters refers to the non-significant differences among months while different letters refers to significant differences at $(p<0.05)$.

\section{Discussion}

Our result about rate of diarrhea (19.43\%) is closely related to report by (7) in Hungary which showed diarrhea incidence in newly calves $(10.5 \%)$ but diarrhea percentage in calves in Southern Italy reach to $16.8 \%$ (14) and the researcher expect this rate able to increase like $19.4 \%$ by ( 6) in Czech Republic ,because occurrence of diarrhea in calves is a result of complex interactions of three sets of factors; the calf, their dam and the calf's environment including management and infectious agents. While, (18) showed diarrheic newly calves (5\%) in Mozambique which that attributed to strict measurement applied on dairy herd by separate pregnant dam from other herds three days before and three day after calving and feeding new borne calf on colostrum freely during three days. The present result of Rota viral infection in diarrheic examined calves (36\%) is closely similar to results obtained by (19) in Brazil as (36.1\%), but it higher than other reports like $17.7 \%$ by ( 20) and $19.4 \%$ by (6) in Belgium, as well as $27 \%$ in India by (13) and $24 \%$ in Sweden (8), but in Swiss, (21) showed rotavirus infection (59\%) by rapid test, also (22) recorded rotavirus infection $(43 \%)$ in Germany. The different rotavirus infection rates in diarrheic calves
Table(4):Relationship between age and bovine rotavirus infection rates.

\begin{tabular}{|c|c|c|c|}
\hline Ages & N0. of samples & positive & $\%$ \\
\hline $1-29$ days & 11 & 5 & $45.4 \mathrm{a}$ \\
\hline 30 -60 days & 7 & 2 & $28.5 \mathrm{~b}$ \\
\hline Total & 18 & 7 & 38.8 \\
\hline
\end{tabular}

Different letters refers to significant differences at $(\mathrm{p}<$ 0.05)

Table(6): The results of Rota viral infection rate in relation to study regions.

\begin{tabular}{|l|c|c|c|}
\hline The region & $\begin{array}{c}\text { No. of } \\
\text { samples }\end{array}$ & positive & $\%$ \\
\hline babylon & 5 & 3 & $60 \mathrm{a}$ \\
\hline AL-Najaf & 5 & 2 & $40 \mathrm{~b}$ \\
\hline Karblaa & 5 & 1 & $20 \mathrm{c}$ \\
\hline AL-Qadisyia & 3 & 1 & $33.3 \mathrm{~b}$ \\
\hline Total & 18 & 7 & 38.8 \\
\hline
\end{tabular}

Similar letters refers to the non-significant differences among region while different letters refers to significant differences at $(p<0.05)$

which established in the present study and by the above other researchers is in agreement with the scientific fact by that rotaviruses a worldwide distribution and able to infect human and domesticated animals. The result from this study show that the rapid test is available tool in diagnosis of rotavirus infection, this assay has the number of advantage including its simple format , rapidity and low cost, and it can be performed without need of trained personnel or expensive equipment also it can read with naked eye, making it easy to perform in every laboratory. Temperature, respiration and heart rate were decline $(38.9,24.5, / \mathrm{min} 99$ beat $/ \mathrm{min})$ respectively and $71.3 \%$ of calves could be depressed and $42.8 \%$ of infected calves continued sucking, while $28.5 \%$ anorectic, also watery, yellowish faces contain indigestible food particles with blood were predominant features of diarrhea in their calves. These clinical signs that showed on diarrheic calves was reported with different degree from moderate till to sever dehydration as well as death of infection calves which reported by (23); (24) and (25). The virus invades the surface epithelial cells of small intestinal villi ,and loss of epithelial cell result in shortened 
villi, which become covered by immature cells arising from the villous crypt. the immature cells and the loss of surface area dramatically reduce the absorptive capacity of the gut and the secretion of normal digestive enzymes. The result is dramatic increase in fluid ,containing undigested and unabsorbed nutrients in gut lumen. The increasing of microbial activity and the osmotic imbalance lead to draw more water into the intestine, the subsequent diarrhea causes weakness, dehydration also acidosis and hypoglycemia, electrolytes losing that lead to respiration and heart work could be affected ,depression and all physiological function may be either alteration or stop in severe cases lead to death. The resultant of effectiveness of sex on infection rate in present study which slightly higher in male than female but non-significant is similar to other finding by (26) whom recorded infection rate $(20.37 \%)$ in male and $(12.76 \%)$ in female, also (27) that found in male higher than in female but without remarkable significant variance. But (28) and showed high rotavirus infection in female than in male but also in non-significant differences. The anatomical ,functional ,hormonal similarities of body systems of male and female calves in early ages lead to non-particular resistance against infection ,but degree of contamination with virus, dose of viruses, exposing to stress factors ,consumption colostrum or non and another many environmental and management factors, all effect on infection rate and severity in both sex of calves in same or different periodic age (30). The present result is in agreement with other resultant by(31) whom had reported highly infection rates at age group as minimum 1 day to maximum of 30 days ,as well as the observations by other group of workers like (27), (24) and (32) which them exhibit that peak rotavirus infection in calves at age 5-15 days .As well as result by (33) indicated that newborn calves of first two months of age were infected with rotavirus but calves more susceptible at first 4 week of age. Animal studies have consistently indicated antibody in lumen of small intestine was of major importance in resistance of rotavirus diseases ,and the pivotal role for local intestine $\operatorname{IgA}$ antibody which are in first day after birth depend on S- IgA from dam colostrum and the level of S-IgA may be increasing with age(34).While, (35) were postulated a hypothesis to explain neonate calves are more susceptible to rotavirus because the enterocyte could be not absorb macromolecules (closure) like S-IgA and S-IgM $36 \mathrm{hrs}$ after birth but micro-molecules can absorbed and enter like rotavirus which replicate and caused pathological processing finally lead to signs of rotavirus infection early. The highest rotavirus infection rate at January in our study is agreement with (36) reported that rotavirus diarrhea had higher prevalence rate in calves during winter months, also in similar with resultant by (37) in which increase Rota viral diarrhea in raining season. Also the present result is agreement with finding by (38) that a major peak of rotavirus infection in neonate calves occur during coldest dried months of year. But (18) in Mozambique showed no seasonal variation in Rota viral diarrhea in occurrence. So (39) explained high rate of Rota viral diarrhea in coldest months due to the suitable climate for still shedding virus a live in micro-environment for a long time relatively and have viability more than in warm months. also he and his team was showing that mean intestinal ,serum immunoglobulin level like IgA, IgM, IgG (which responsible to prevent or less severity of rotavirus infection ) were lowest in winter and increasing during spring and early Summer. As well as above many reasons, in Iraq most calving occur in end of autumn and firstly month of winter in which these ages are more susceptible for Rota viral infection, that Summarized high Rota viral infection incidence in autumn and winter month. Incidence or Rota viral diarrhea was established in four provinces with significant increasable in Babylon in similar to previous studies some Iraq provinces like in Mosul $15.5 \%$ (15), (16) in Basrah province 25\% ,and the variation between rate infection in these provinces which in same of geographical ,seasonal condition as well as the same animals breed and method of breeding, therefore these variance could be 
attributed to management measurement at animal herd, also number of randomly fecal samples that collected, previously Rota viral infection finding. Babylon province has a large animals market which visiting by large number of peoples to sale or purchase

\section{References}

1-Lorenz I, Fagan J and More SJ (2011).Calf health from birth to weaning. management of diarrhea in pre-weaned calves .IR Vet. J.64(1):9.

2-Garcia JC, Corral NG, Halaihil MC, Simon JL, Alonso JL, Muzqiz C, Ortega A and Girones O (1993).Survey of rotavirus infection in adairy herd :Comparison between polyacrylamidegel electrophoresis and two commercial tests. Vet .Microbiol., 34:321-332.

3-GotoY , Kurgi H , Inaba C and Matumoto M (1986 ). Sequential of rotavirus from individual calves .Vet .Microbiol., 34:321-332.

4-Kapikian AZ and Chanock RM (1990). Rotaviruses. Fields and Virology, 4th ed. Lippincott Williams and Wilkins,Philadelphia, p: 1657-1708.

5-Acres SD, Saunders J R and Raix OM (1977). Acuteundifferentiated neonatal diarrhea of beef calves. The prevalence ofenterotoxigenicE. coli, reo-like (rota) virus and other enteropatbogens in cow-calf herds. Canadian Veterinary Journal 18: 113-121.

6-Alfieri A A, Parazzi M E, Takiuchi E, Medici K C and Alfieri AF (2006). Frequency of group A rotavirus in diarrheic calves in Brazilian cattle herd ,1998-2002.Tropical Animal Health and Production, 38:521-526.

7-Duman R and Aycan AE (2010). Prevalence of rotavirusinfection in calves with diarrhea in Konya region. J. Anim., Vet. Adv., 9(1) :136-138.

8-deVerdier K (2006).Infektionspanoramat vid diarréer hos svenskakalvar. Thepanorama of infection in Swedish calves with diarrhoea. Svensk Veterinärtidning, 58:29-32.(Abstract).

9-Reynolds DJ, Morgan JH, Chanter N, Jones PW, Bridger JC, Debney TG and Bunch KJ (1986). Microbiology of calf diarrhoea in southern Britain. The Veterinary Record ,119:34-42.

10-Pérez E, Kummeling A, Janssen MM, Jiménez C, Alvarado R, Caballero $\mathrm{M}$, Donado $\mathrm{P}$ and Dwinger RH (1998). Preventive Veterinary Medicine, 33:195-205.

11-Lucchelli A, Lance SE, Bartlett PB, Miller GY and Saif LJ (1992). Prevalence ofbovine group A rotavirus shedding among dairy calves in Ohio. American Journal of Veterinary Research ,53: 169174.

12-Bendali F, Bichet H, Schelcher F and Sanaa M (1999). Pattern of diarrhoea innewborn beef calves in south-west France. Veterinary Research ,30: 6174.

13-Sukhija Y and Grover YP (2003).The application of latex agglutination test for the detection of different animals from all Iraq area at each Friday in AL-Qassim city, that explain Babylon became source of infection, then distributed infection to neighboring provinces.

bovine rotaviruses in diarrhoeic fecal samples and its comparison with ELISA and RNA-PAGE Journal of Immunology and Immunopathology , 5( Issue 2): 34.

14-Pisanelli G, Martella V, Pagnini U, Demartino L, Lorusso E, Iovane G and Buonavogalia C (2005). Distribution of G. (VP7) and (VP4) genotypes in buffalo group A rotaviruses. Indain J Med Res., 21:206.

15-Al-Robaiee IA and Farwachi M I (2013). Prevalence of rotaviral infection in diarrheic neonatal calves in Mosul city, Iraq. Vet Rec. ,6(8): 538-540

16-Hekmat KA (2010). Detection of Rotavirus Antigens and Antibodies in Children and Bovine.Thesis. College of Veterinary Medicine. Basrah. Iraq.

17-Dhama K, Chauhan RS, Mahendran M and Malik SV (2009). Rotavirus diarrhea in bovine and other domastic animals. Vet .Res .common .,33(1):1-3.

18-Acha SJ, Kuhn P, Jonsson G, Mbazima M and Katouli AA (2004). Studies on Calf Diarrhoea in Mozambique: Prevalence of Bacterial Pathogens.Acta Veterinaria Scandinvica , 45:27.

19-Langoni H, Antonio C L, Fernando A A, Aristeu V D and Acacia O E (2004).Contribution to the study of diarrhea etiology in neonate dairy calves in São Paulo state, Brazil Braz. J. Vet. Res. Anim. Sci., 41(5):12-16

20-Bartels CJ, Holzhauer M, Jorritsma R, Swart WA and Lam TJ (2010). Prevalence, Prediction and Riskfactors of enteropathogens in normal and nonnormal faeces of young dutch dairy calves .Prve Vet J., 93(2-3): 162-169.

21-Uhde FL, Kaufmann H, Sager S, Albini R, Zanoni E, Schelling E and Meylan M (2008). Prevalence of four enteropathogens in the faeces of young diarrhoeic dairy calves in Switzerland. Vet. Rec., 163: 362-366.

22-Luginbühl A, Reitt K, Metzler A, Kollbrunner M, Corboz Land Deplazes P (2005). Diarrhea in neonatal ruminants :intestinal diseases in ruminants : Merk veterinary manual P: 245-252.

23-Janic Cand Bridger L (1994).Adefinition of bovine rotavirus virulence.Journal of Genral Virology.75:2807-2812.

24-Radostits OM, Gay CC, Hinchcliff KW and Constable PD (2007). Veterinary Medicine, A textbook of the diseases of cattle, horses, sheep, pigs, and goats, 10th edn. Saunders-Elsevier, Philadelphia: 1286-1296.

25-Chauhan RS, Dhama $\mathrm{K}$ and Mahendran $\mathrm{M}$ (2008).Pathobiological of rotaviral diarrhea in 
calves and its diagnosis and contol:A review. Journal of Immunology and Immunopathology. 10(lssue:1):1-13.

26-Dash SK ,Tewari A, Krishna K, Goel A and Bhatia K (2011). Detection of Rotavirus from diarrhoeic cow calves in Mathura, India Vet Rcord ,4(12): 554-556.

27-Nataraju SM, Chattopadhyay UK and Krishnan T (2009). A study on the possibility of zoonotic infection in rotaviral diarrhoea among calves and buffalo calves in and around Kolkata, India.Eur Rev Med Pharmacol Sci.,13(1):7-11.

28-Alam M N, Alam MM, Nahar A and Kobayashi K (2011). Molecular epidemiological studies on rotavirus infection causing severe diarrhea in human and animal. Bangladesh J Vet Med.,9 (2): 32-37.

29-Hasso S A and Pandey R (1986). Possible sex differences in thesusceptibility of calves to rotavirus infection .Can.J.Vet., 50(2):287-288.

30-Haschek B, Klein D, Benetka V, Herrera C, Sommerfeld I, Vilcek S, Moesh $\mathrm{H}$ and Baumgartner M (2006).Detection of bovine rotavirus in neonatal calf diarrhea in Lower Austria and Styria (Austria).JVM B.,5:42-44.

31-Chinsangagram $\mathrm{R}$, Kohara $\mathrm{J}$ and Tsunemitsu $\mathrm{H}$ (1993). Correlation between maternal serum antibodies and protection against bovine rotavirus diarrhea in calves. The Journal Veterinary Medical Science, 62: 219-221.

32-Brooks AE, Manning K ,Wang C, Taylor JA, Ge Y, Mansell A and Ussher JE (2013).Rotavirus
NSP4 Triggers Secretion of Proinflammatory Cytokines from Macrophages via Toll-Like Receptor 2. J Virol. ,87(20):11160-7.

33-Sharma R, Garrison RD, Tepas JJ, Mollitt DL, Pieper P, Hudak ML, Bradshaw JA, Stevens G and Premachandra BR (2004). Rotavirus-associated necrotizing enterocolitis: an insight into a potentially preventable disease. Journal of Pediatric Surgery ,39:453-7.

34-Desselberger Uand Hupertz H (2011). Immune response of rotavirus infection and vaccination associated correlates' of protection. Journal of Infectious Diseases. 1:188-195.

35-Hurely WL and Theil PK (2011). Perspectiveon Immunoglobulins in colostrums and milk. Nutrients, 3:442-474.

36-Dodet B, Hesseltine E, Mary C and Salion P (1997).Rotavirus in human and veterinary medicine. Sant., 7(3):195-199.

37-Broor S, Ghosh D and Mathur P (2003).Molecular epidemiology of rotaviruses in India. Indain $\mathrm{J}$ Med Res.,118:59-67.

38-Kapikian A Z, Hoshino Y and Chanock R M (2001). Rotavirus, In: Fields Virology. D. M. Knipe and P. M. Howley (eds.). $4^{\text {th }}$ ed., Lippincott Williams and Wilkins, Philadelphia., 1787-1833.

39-Norheim K, Simensen E and Gjestang K (2005). The relationship between serum IgG level and age, weight gain in rotaviral infection in dairy calves. Nord.Vet.Med.,37:113-120. 